\section{AMERICAN-EURASIAN JOURNAL OF SUSTAINABLE AGRICULTURE}

\title{
Effect of Nitrogen Fertilizer Rates and Plant Densities on Safflower (Carthamus tinctorius L.) yield and Quality under Arid Land Conditions
}

\author{
Mohammad Garallah Albogami*, Fathy S. El-Nakhlawy and Samir G. Al-Solaimani \\ Arid Land Agriculture Department, Faculty of Meteorology, Environment and Arid Land Agriculture, King Abdulaziz University, Jeddah,
} Saudi Arabia

Received date: 18 September 2018, Accepted date: 15 November 2018, Online date: 20 December 2018

\author{
Address for Correspondence: \\ Mohammad Garallah Albogami, Arid Land Agriculture Department, Faculty of Meteorology, Environment and Arid Land Agriculture, \\ King Abdulaziz University, Jeddah, Saudi Arabia \\ E-mail: themigrent2007@ hotmail.com
}

Copyright $\odot 2018$ by authors and American-Eurasian Network for Scientific Information.

This work is licensed under the Creative Commons Attribution International License (CC BY).

http://creativecommons.org/licenses/by/4.0/

\section{(C) (i) Open Access}

\begin{abstract}
This investigation was carried out at the Agriculture Research Station, King Abdul-Aziz University at Hada AL-Sham, Jeddah, Saudi Arabia during 2016/2017 and 2018/2018 seasons. Four nitrogen fertilizer rates (46, 92, 138and $184 \mathrm{~kg} \mathrm{~N} / \mathrm{ha}$ ) and three plant densities $(250,000,125,000$ and 83,333 plants/ha) were applied and tested on safflower seed yield, yield components and quality in a split plot design. The obtained results showed that as nitrogen fertilizer rate increased up to $138 \mathrm{~kg} \mathrm{~N} / \mathrm{ha}$ safflower seed yield and yield components significantly increased. No significantly difference was found between $138 \mathrm{~kg} \mathrm{~N} / \mathrm{ha} \mathrm{and} 184 \mathrm{~kg}$ $\mathbf{n} / \mathbf{h a}$ in seed yield/ha. Plant density of $\mathbf{8 3 , 3 3 3}$ plants / ha was the highest in seed yield/ha, yield components, protein and oil contents of seeds compared with 250,000 plants/ha and 125,000 plants/ha. Increasing nitrogen fertilizer rate significantly increased protein content and decreased oil content of safflower seed.

KEY WORDS

Chlorophyll, nitrogen fertilizer, oil, plant density safflower, protein.
\end{abstract}

\section{INTRODUCTION}

Safflower is an edible oil crop and oil extracted from safflower is rich in unsaturated fatty acids (oleic and linoleic acids) and low in saturated fatty acids (stearic and palmitic acids). A sufficient amount of nitrogen is to be supplied for a plant to achieve optimum growth, yield and high-quality production [1]. Nitrogen is the main nutrient that affects the growth, yield and quality of safflower [2] [3]. Nitrogen fertilizers significantly increase seed weight/plant and other yield components [4] [5] [6], [7] and [8]. When the nitrogen fertilizer rate is increased, there is a significant increase observed in seed yield and protein content of safflower [9] and [10]. The plant density and nitrogen fertilizer rate significantly affect the growth parameters, seed yield and yield attributes. The number of branches and heads/plant significantly increased as the plant density decreased [11]. Plant density significantly affects safflower yield. 80,000 safflower plants/ha increased seed yield /plant and pre-hectare [12]. High plant density increases the seed yield [13] and oil content [14]. Other studies stated that the high plant density decreased the number of branches/plants, heads / plant and seed yield / ha. When the plant density increased, it resulted in decreased seed yield and oil yield /ha [15].

This study was conducted to improve safflower seed yield, oil and protein contents under the arid land conditions through determination the best nitrogen fertilizer rate and plant density. 

tinctorius L.) yield and Quality under Arid Land Conditions/ American-Eurasian Journal of Sustainable Agriculture. 12(4) October-December 2018, Pages: 1-6. DOI: 10.22587/aejsa.2018.12.4.1

Location and treatments of the Experiment

\section{MATERIALS AND METHODS}

This study was carried out at the Agriculture Research Station, King Abdulaziz University at Hada AL-Sham, Jeddah, Saudi Arabia during 2016/2017 and 2017/2018 seasons. A split plot design with 4 replicates was used in this study. The main plot treatments were 4 nitrogen fertilizer rates $(46,92,138$ and $184 \mathrm{~kg} \mathrm{~N} / \mathrm{ha})$ while the Sub plots were occupied with 3 plant densities (S1: 250,000, S2: 125,000 and S3: 83.333 plants /ha). Safflower cultivar of Giza-101 was used in this study. Sub plot consisted from 10 rows with $40 \mathrm{~cm}$ as a row spacing. The plant spacing within the raw were 10, 20 and $30 \mathrm{~cm}$ for the S1, S2 and S3 plant densities, respectively.

The soil of the experiment was sandy loam with sand (70.85\%), nitrogen level equal $1320 \mathrm{mg} \mathrm{kg}-1 \mathrm{soil}$, phosphorus (30 mg kg -1soil), potassium (286 mgkg -1soil) and $1.32 \%$ organic matter as a result of the soil analysis according to [16]. The cultural practices of the crop were done according to [17]. Total chlorophyll $(\mathrm{mg} / \mathrm{g})$, was extracted from the fresh leaves of each sub plot sample by acetone $(80 \%)$. The spectrophotometer readings of the samples were measured using Spectrophotometer (Spectrophotometer Model 6120, PerkinElmer) at wavelength $663 \mathrm{~nm}$. The equations of [23] were used to calculate the total chlorophyll concentrations $(\mathrm{mg} / \mathrm{g})$ in the leaves. Also, the following characteristics were measured: number of heads/plants, seed weight /plant (g), seed yield/ha (t), oil content of the seeds using Soxhlet apparatus using N-Hexane (60C) as an organic solvent [18] and seed protein content using Kjeldahel instrument [18].

Statistical Analysis

The obtained data of the 2 seasons were statistically analyzed through analysis of variance (ANOVA) then the means of the traits under the main factors and interaction treatments were separated and statistically compared using Revised Least Significance Difference test (RLSD) according to [19] using [20] SAS (2014).

\section{Effect of nitrogen Fertilizer Rates}

\section{RESULTS}

\section{Total chlorophyll of leaves}

The total chlorophyll of safflower leaves positively affected by increasing Nitrogen fertilizer rate up to $138 \mathrm{~kg}$ $\mathrm{N} /$ ha with significant differences between the rates of 46, 92 and $138 \mathrm{~kg}$ N/ha. No significant differences was found between total chlorophyll content of leaves under $138 \mathrm{~kg} \mathrm{~N} / \mathrm{ha}$ and $184 \mathrm{~kg} \mathrm{~N} / \mathrm{ha}$ in both seasons. Total chlorophyll contents ranged from 1.51 to $1.78 \mathrm{mg} / \mathrm{g}$ in the first season and from 1.51 to $1.77 \mathrm{mg} / \mathrm{g}$ in the second season (Table1).

\section{Number of heads per plant}

The highest no. of heads /plant were showed under the $184 \mathrm{~kg} \mathrm{~N} / \mathrm{ha}$ without insignificant difference with $138 \mathrm{~kg}$ $\mathrm{N} / \mathrm{ha}$ in both seasons. The lowest no. of heads / plant were detected under the $46 \mathrm{~kg} \mathrm{~N} / \mathrm{ha}$ in both seasons. No. of heads / ha ranged from 20.20 to 14.93 heads / plant in the 1st season and from 18.08 to 13.11 heads / plant in the second season (Table 1).

\section{Seed weight per plant}

The obtained data of Table (1) showed insignificant differences were found between the $138 \mathrm{~kg} \mathrm{~N} / \mathrm{ha}$ and 184 $\mathrm{kg} \mathrm{N} / \mathrm{ha}$ in seed weight /plant in both seasons. In addition, no significant difference was showed between seed weight / plant under the $46 \mathrm{~kg} \mathrm{~N} / \mathrm{ha}$ and $92 \mathrm{~kg} \mathrm{~N} / \mathrm{ha}$ in both seasons. The highest seed weight / plant were 18.70 $\mathrm{g}$ and $15.87 \mathrm{~g} / \mathrm{plant}$ in the 1 st and 2 nd seasons, respectively. The lowest seed weights/ plant were $16.08 \mathrm{~g}$ and $12.95 \mathrm{~g} /$ plant in the 2 seasons, respectively.

Table 1. Means of total chlorophyll content of leaves (mg/g), no. of heads / plant and seed weight / plant (g) of safflower under the effect of four nitrogen rates during 2016/2017 and 2017/2018 seasons.

\begin{tabular}{|c|c|c|c|c|c|c|}
\hline \multirow{3}{*}{$\begin{array}{l}\text { Nitrogen } \\
\text { fertilizer rate } \\
(\mathrm{Kg} \mathrm{N} / \mathrm{ha})\end{array}$} & \multicolumn{6}{|l|}{ Means } \\
\hline & \multicolumn{2}{|c|}{$\begin{array}{l}\text { Total chlorophyll content } \\
(\mathrm{mg} / \mathrm{g})\end{array}$} & \multicolumn{2}{|c|}{ No. of heads/plant } & \multicolumn{2}{|c|}{$\begin{array}{l}\text { Seed weight/ plant } \\
(\mathrm{g})\end{array}$} \\
\hline & $2016 / 2017$ & $2017 / 2018$ & $2016 / 2017$ & $2017 / 2018$ & $2016 / 2017$ & $2017 / 2018$ \\
\hline 46 & $1.51 \mathrm{c}^{*}$ & $1.51 \mathrm{c}$ & $14.93 \mathrm{c}$ & $13.11 \mathrm{c}$ & $16.08 \mathrm{~b}$ & $12.95 \mathrm{~b}$ \\
\hline 92 & $1.58 \mathrm{~b}$ & $1.57 \mathrm{~b}$ & $17.91 \mathrm{~b}$ & $16.03 \mathrm{~b}$ & $16.73 \mathrm{~b}$ & $13.05 \mathrm{~b}$ \\
\hline 138 & $1.73 \mathrm{a}$ & $1.73 \mathrm{a}$ & $17.99 \mathrm{ab}$ & $16.95 \mathrm{ab}$ & $17.75 \mathrm{a}$ & $15.25 \mathrm{a}$ \\
\hline 184 & $1.78 \mathrm{a}$ & $1.77 \mathrm{a}$ & $20.20 \mathrm{a}$ & $18.08 \mathrm{a}$ & $18.7 \mathrm{a}$ & $15.87 \mathrm{a}$ \\
\hline RLSD(0.05) & 0.06 & 0.02 & 2.23 & 1.38 & 1.16 & 1.42 \\
\hline
\end{tabular}

*Means followed by different letter are significantly different according to RLSD at $\mathrm{P} \leq 0.05$. 

tinctorius L.) yield and Quality under Arid Land Conditions/ American-Eurasian Journal of Sustainable Agriculture. 12(4) October-December 2018, Pages: 1-6. DOI: 10.22587/aejsa.2018.12.4.1

\section{Seed yield per hectare}

Significant differences were showed between seed yield / ha under the 3 nitrogen fertilizer rates of 46, 92 and $138 \mathrm{~kg} \mathrm{~N} / \mathrm{ha}$, but no significant differences were found between the $138 \mathrm{~kg} \mathrm{~N} /$ ha and $184 \mathrm{~kg} \mathrm{~N} / \mathrm{ha}$ in both seasons. Seed yield /ha ranged from $3.22 \mathrm{t} / \mathrm{ha}$ to $1.92 \mathrm{t} / \mathrm{ha}$ in the first season and from $3.01 \mathrm{t} / \mathrm{ha}$ to $1.34 \mathrm{t} / \mathrm{ha}$ in the second season under $138 \mathrm{~kg} \mathrm{~N} /$ ha and $46 \mathrm{~kg} \mathrm{~N} /$ ha, respectively (Table 2).

\section{Oil content}

The statistical comparisons of seed oil content mean under the four nitrogen fertilizer rates in the 2 studied seasons showed that the highest oil contents were $36.53 \%$ and $36.25 \%$ under the $92 \mathrm{~kg} \mathrm{~N} / \mathrm{ha}$ in the first and second seasons, respectively and significant difference from the others nitrogen rates. The lowest oil contents were showed under the $184 \mathrm{~kg} \mathrm{~N} / \mathrm{ha}$ in both seasons with values of $34.13 \%$ and $34.88 \%$ in the first and second seasons respectively as show in (Table 2).

\section{Protein content}

The obtained results of seed protein contents under the four nitrogen fertilizer rates in both seasons (Table 2) revealed that as nitrogen fertilizer rate increased, protein content significantly increased. Protein content ranged from $14.28 \%$ to $16.89 \%$ in the first seasons and from $14.47 \%$ to $16.54 \%$ in the second seasons under $46 \mathrm{~kg} \mathrm{~N} /$ ha and $184 \mathrm{~kg} \mathrm{~N} /$ ha, respectively.

Table 2. Means of seed yield / ha (t), seed oil content $(\%)$ and seed protein content $(\%)$ of safflower under the effect of four nitrogen rates during 2016/2017 and 2017/2018 seasons.

\begin{tabular}{|c|c|c|c|c|c|c|}
\hline \multirow{3}{*}{$\begin{array}{l}\text { Nitrogen } \\
\text { fertilizer rate } \\
(\mathrm{Kg} \mathrm{N} / \mathrm{ha})\end{array}$} & \multicolumn{6}{|l|}{ Means } \\
\hline & \multicolumn{2}{|c|}{$\begin{array}{l}\text { Seed yield / ha } \\
\text { (t) }\end{array}$} & \multicolumn{2}{|l|}{$\begin{array}{l}\text { Oil content } \\
(\%)\end{array}$} & \multicolumn{2}{|c|}{$\begin{array}{l}\text { Protein content } \\
(\%)\end{array}$} \\
\hline & $2016 / 2017$ & $2017 / 2018$ & $2016 / 2017$ & $2017 / 2018$ & $2016 / 2017$ & $2017 / 2018$ \\
\hline 46 & $1.92 \mathrm{c} *$ & $1.34 \mathrm{c}$ & $34.55 \mathrm{c}$ & $35.03 \mathrm{c}$ & $14.28 \mathrm{~d}$ & $14.47 \mathrm{~d}$ \\
\hline 92 & $2.87 \mathrm{~b}$ & $2.60 \mathrm{~b}$ & $36.53 \mathrm{a}$ & $36.25 \mathrm{a}$ & $15.33 \mathrm{c}$ & $15.11 \mathrm{c}$ \\
\hline 138 & $3.29 \mathrm{a}$ & $3.01 \mathrm{a}$ & $35.01 \mathrm{~b}$ & $35.85 \mathrm{~b}$ & $16.09 \mathrm{~b}$ & $16.08 \mathrm{~b}$ \\
\hline 184 & $3.22 \mathrm{a}$ & $2.85 \mathrm{a}$ & $33.13 \mathrm{~d}$ & $34.88 \mathrm{~d}$ & $16.89 \mathrm{a}$ & $16.54 \mathrm{a}$ \\
\hline RLSD (0.05) & 0.22 & 0.21 & 0.17 & 0.11 & 0.071 & 0.14 \\
\hline
\end{tabular}

*Means followed by different letter are significantly different according to RLSD at $\mathrm{P} \leq 0.05$.

\section{Effect of plant density}

Total chlorophyll

The presented data in (Table 3) showed that as plant density increased total chlorophyll in safflower leaves significantly increased in both seasons. The highest total chlorophyll were $1.68 \mathrm{mg} / \mathrm{g}$ and $1.69 \mathrm{mg} / \mathrm{g} \mathrm{under}$ 83,333 plants / ha, while the lowest total chlorophyll were $1.62 \mathrm{mg} / \mathrm{g}$ and $1.58 \mathrm{mg} \mathrm{mg} / \mathrm{g}$ under 250,000 plants / ha in both seasons, respectively.

\section{Seed yield and yield components}

The statistical comparisons between the means of seed yield or yield components (number of heads / plant and seed weight / plant) showed that the highest seed yield in both seasons were produced from the lowest plant density and the lowest seed yield were produced from the highest plant density in both seasons. The highest seed yield / ha in the $1^{\text {st }}$ and $2^{\text {nd }}$ seasons were $2.83 \mathrm{t} /$ ha and $2.52 \mathrm{t} / \mathrm{ha}$, respectively. The lowest seed yield /ha were $2.45 \mathrm{t}$ /ha and $2.38 \mathrm{t} / \mathrm{ha}$ in the $1^{\text {st }}$ and $2^{\text {nd }}$ seasons, respectively (Table 4 ). Number of heads / plant and seed weight/ plant significantly increased as plant density decreased. The highest number of heads / plant in both seasons were 20.52 and 18.42 under 83,333 plant density and the lowest number of heads / ha in both seasons were 14.20 and 13.54 under 250,000 plants /ha. In addition, the highest seed weight / plant were showed under the lowest plant density and the lowest seed weight / plant was found under the highest plant density in both seasons. Seed weight / plant ranged from $13.92 \mathrm{~g}$ to $20.5 \mathrm{~g} /$ plant and from $13.47 \mathrm{~g}$ to $14.86 \mathrm{~g} /$ plant in the first and second seasons, respectively (Table 3). 
Albogami, M.G et al., 2018. Effect of Nitrogen Fertilizer Rates and Plant Densities on Safflower (Carthamus tinctorius L.) yield and Quality under Arid Land Conditions/ American-Eurasian Journal of Sustainable Agriculture. 12(4) October-December 2018, Pages: 1-6. DOI: 10.22587/aejsa.2018.12.4.1

Table 3 Means of total chlorophyll (mg/g), no. of heads/plant and seed weight/ plant ( $\mathrm{g}$ ) of safflower under the effect of three plant density during 2016/2017 and 2017/2018 seasons.

\begin{tabular}{|l|l|l|l|l|l|l|}
\hline \multirow{2}{*}{\begin{tabular}{l} 
Plant $\begin{array}{l}\text { density } \\
\text { (plants/ha) }\end{array}$ \\
\cline { 2 - 7 }
\end{tabular}} & \multicolumn{3}{|l|}{ Teans } & \multicolumn{2}{l|}{ No. of heads/plant } & \multicolumn{2}{l|}{$\begin{array}{l}\text { Seed weight/ plant } \\
(\mathrm{g})\end{array}$} \\
\cline { 2 - 7 } & $2016 / 2017$ & $2017 / 2018$ & $2016 / 2017$ & $2017 / 2018$ & $2016 / 2017$ & $2017 / 2018$ \\
\hline 250,000 & $1.62 \mathrm{c} *$ & $1.58 \mathrm{c}$ & $14.20 \mathrm{c}$ & $13.54 \mathrm{c}$ & $13.92 \mathrm{c}$ & $13.47 \mathrm{~b}$ \\
\hline 125,000 & $1.65 \mathrm{~b}$ & $1.64 \mathrm{~b}$ & $17.52 \mathrm{~b}$ & $16.18 \mathrm{~b}$ & $17.62 \mathrm{~b}$ & $14.51 \mathrm{a}$ \\
\hline 83,333 & $1.68 \mathrm{a}$ & $1.69 \mathrm{a}$ & $20.52 \mathrm{a}$ & $18.42 \mathrm{a}$ & $20.51 \mathrm{a}$ & $14.86 \mathrm{a}$ \\
\hline RLSD $(0.05)$ & 0.021 & 0.02 & 0.71 & 1.83 & 1.87 & 1.09 \\
\hline
\end{tabular}

*Means followed by different letter are significantly different according to RLSD at $\mathrm{P} \leq 0.05$.

Table 4. Means of seed yield / ha (t), oil content $(\%)$ and protein content $(\%)$ of safflower under the effect of plant density during 2016/2017 and 2017/2018 seasons.

\begin{tabular}{|c|c|c|c|c|c|c|}
\hline \multirow{3}{*}{$\begin{array}{l}\text { Plant } \\
\text { density } \\
\text { (plants/ha) }\end{array}$} & \multicolumn{6}{|l|}{ Means } \\
\hline & \multicolumn{2}{|c|}{$\begin{array}{l}\text { Seed yield / ha } \\
\text { (t) }\end{array}$} & \multicolumn{2}{|l|}{$\begin{array}{l}\text { Oil content } \\
(\%)\end{array}$} & \multicolumn{2}{|c|}{$\begin{array}{l}\text { Protein content } \\
(\%)\end{array}$} \\
\hline & $2016 / 2017$ & $2017 / 2018$ & $2016 / 2017$ & $2017 / 2018$ & $2016 / 2017$ & $2017 / 2018$ \\
\hline 250,000 & $2.45 \mathrm{c}^{*}$ & $2.38 \mathrm{c}$ & $34.50 \mathrm{c}$ & $34.95 \mathrm{c}$ & $15.45 \mathrm{c}$ & $15.34 \mathrm{c}$ \\
\hline 125,000 & $2.58 \mathrm{~b}$ & $2.45 \mathrm{~b}$ & $34.89 \mathrm{~b}$ & $35.43 \mathrm{~b}$ & $15.61 \mathrm{~b}$ & $15.55 \mathrm{~b}$ \\
\hline 83,333 & $2.83 \mathrm{a}$ & $2.52 \mathrm{a}$ & $35.03 \mathrm{a}$ & $36.14 \mathrm{a}$ & $15.89 \mathrm{a}$ & $15.77 \mathrm{a}$ \\
\hline RLSD (0.05) & 0.08 & 0.06 & 0.13 & 0.09 & 0.051 & 0.09 \\
\hline
\end{tabular}

*Means followed by different letter are significantly different according to RLSD at $\mathrm{P} \leq 0.05$

Effect of the interaction between nitrogen fertilizer rate and plant density

The presented results of the studied traits under the interaction treatments between nitrogen fertilizer rates and plant density (Tables 5 and 6) showed no significant differences were showed between the 12 interaction treatments for the six studied traits. Total chlorophyll content ranged from $1.79 \mathrm{mg} / \mathrm{g}$ to $1.47 \mathrm{mg} / \mathrm{g}$ in the first season and from $1.79 \mathrm{mg} / \mathrm{g}$ to $1.45 \mathrm{mg} / \mathrm{g}$ in the second season. Number of heads / plants ranged from 23.40 to 12.38 and from 21.25 to 12.56 in both seasons, respectively. Seed weight /plant ranged from 21.18 to 12.84 and from 16.94 to 12.88 in the $1^{\text {st }}$ and $2^{\text {nd }}$ seasons, respectively.

Table 5. Means of total chlorophyll (mg/g), no. of heads/plant and seed weight/ plant $(\mathrm{g})$ of safflower under the effect of the interaction between nitrogen fertilizer rate and plant density during 2016/2017 and 2017/2018 seasons.

\begin{tabular}{|c|c|c|c|c|c|c|c|}
\hline \multirow{3}{*}{$\begin{array}{l}\text { Nitrogen } \\
\text { fertilizer rate } \\
(\mathrm{KgN} / \mathrm{ha})\end{array}$} & \multirow{3}{*}{$\begin{array}{l}\text { Plant } \\
\text { density } \\
\text { (plants/ha) }\end{array}$} & \multicolumn{6}{|l|}{ Means } \\
\hline & & \multicolumn{2}{|c|}{$\begin{array}{l}\text { Total chlorophyll } \\
(\mathrm{mg} / \mathrm{g})\end{array}$} & \multicolumn{2}{|c|}{ No. of heads/plant } & \multicolumn{2}{|c|}{$\begin{array}{l}\text { Seed weight/ plant } \\
(\mathrm{g})\end{array}$} \\
\hline & & $2016 / 2017$ & $2017 / 2018$ & $2016 / 2017$ & $2017 / 2018$ & $2016 / 2017$ & $2017 / 2018$ \\
\hline \multirow[t]{3}{*}{46} & 250,000 & 1.47 & 1.45 & 12.38 & 12.50 & 12.84 & 12.99 \\
\hline & 125,000 & 1.52 & 1.52 & 15.98 & 12.57 & 17.97 & 12.88 \\
\hline & 83,333 & 1.55 & 1.57 & 15.98 & 14.28 & 17.43 & 12.99 \\
\hline \multirow[t]{3}{*}{92} & 250,000 & 1.55 & 1.52 & 15.66 & 13.43 & 11.90 & 13.36 \\
\hline & 125,000 & 1.58 & 1.58 & 17.46 & 16.12 & 19.29 & 12.35 \\
\hline & 83,333 & 1.63 & 1.63 & 20.26 & 18.53 & 18.99 & 13.43 \\
\hline \multirow[t]{3}{*}{138} & 250,000 & 1.70 & 1.68 & 14.02 & 13.98 & 14.29 & 13.54 \\
\hline & 125,000 & 1.73 & 1.72 & 18.45 & 17.28 & 20.03 & 16.14 \\
\hline & 83,333 & 1.76 & 1.78 & 21.50 & 19.60 & 18.92 & 16.074 \\
\hline \multirow[t]{3}{*}{184} & 250,000 & 1.76 & 1.67 & 15.05 & 14.25 & 14.64 & 14.00 \\
\hline & 125,000 & 1.78 & 1.76 & 22.16 & 18.73 & 21.18 & 16.68 \\
\hline & 83,333 & 1.79 & 1.79 & 23.40 & 21.25 & 18.68 & 16.94 \\
\hline \multicolumn{2}{|l|}{ RLSD (0.05) } & NS & NS & NS & NS & NS & NS \\
\hline
\end{tabular}

NS: not significant according to RLSD at $\mathrm{P} \leq 0.05$ 
Albogami, M.G et al., 2018. Effect of Nitrogen Fertilizer Rates and Plant Densities on Safflower (Carthamus tinctorius L.) yield and Quality under Arid Land Conditions/ American-Eurasian Journal of Sustainable Agriculture. 12(4) October-December 2018, Pages: 1-6. DOI: 10.22587/aejsa.2018.12.4.1

Seed yield /ha ranged from $3.33 \mathrm{t} / \mathrm{ha}$ to $1.86 \mathrm{t} / \mathrm{ha}$ and from $3.29 \mathrm{t} / \mathrm{ha}$ to $1.01 \mathrm{t} / \mathrm{ha}$ in the first and $2^{\text {nd }}$ seasons, respectively. Oil content ranged from $35.15 \%$ to $33.87 \%$ in the first season and from $37.03 \%$ to $34.39 \%$ in the second season. Protein content ranged from $17.25 \%$ to $14.04 \%$ in the first season and $16.76 \%$ to $14.33 \%$ in the second season as shown in (Table 6).

Table 6. Means of Seed yield / ha (t), oil (\%) and Protein content (\%) of safflower under the effect of the interaction between nitrogen fertilizer rate and plant density during 2016/2017 and 2017/2018 seasons.

\begin{tabular}{|c|c|c|c|c|c|c|c|}
\hline \multirow{3}{*}{$\begin{array}{l}\text { Nitrogen } \\
\text { fertilizer } \\
\text { rate } \\
(\mathrm{Kg} \mathrm{N} / \mathrm{ha})\end{array}$} & \multirow{3}{*}{$\begin{array}{l}\text { Plant } \\
\text { density } \\
\text { (plants / } \\
\text { ha }\end{array}$} & \multicolumn{6}{|l|}{ Means } \\
\hline & & \multicolumn{2}{|c|}{$\begin{array}{l}\text { Seed yield / ha } \\
\text { (t) }\end{array}$} & \multicolumn{2}{|l|}{$\begin{array}{l}\text { Oil } \\
\quad(\%)\end{array}$} & \multicolumn{2}{|c|}{$\begin{array}{l}\text { Protein content } \\
(\%)\end{array}$} \\
\hline & & $2016 / 2017$ & $2017 / 2018$ & $2016 / 2017$ & $2017 / 2018$ & $2016 / 2017$ & $2017 / 2018$ \\
\hline \multirow[t]{3}{*}{46} & 250,000 & 1.86 & 1.88 & 33.87 & 34.39 & 14.04 & 14.33 \\
\hline & 125,000 & 1.90 & 1.12 & 34.61 & 34.94 & 14.29 & 14.47 \\
\hline & 83,333 & 1.98 & 1.01 & 35.18 & 35.75 & 14.52 & 14.62 \\
\hline \multirow[t]{3}{*}{92} & 250,000 & 2.84 & 2.19 & 36.27 & 35.64 & 15.24 & 14.92 \\
\hline & 125,000 & 2.84 & 2.72 & 36.59 & 36.11 & 15.33 & 15.09 \\
\hline & 83,333 & 2.93 & 2.89 & 36.71 & 37.03 & 15.41 & 15.34 \\
\hline \multirow[t]{3}{*}{138} & 250,000 & 3.27 & 2.86 & 34.82 & 35.33 & 15.93 & 15.84 \\
\hline & 125,000 & 3.30 & 3.86 & 35.15 & 35.82 & 15.96 & 16.05 \\
\hline & 83,333 & 3.33 & 3.29 & 34.99 & 36.40 & 16.39 & 16.36 \\
\hline \multirow[t]{3}{*}{184} & 250,000 & 3.33 & 2.60 & 33.05 & 34.44 & 16.57 & 16.26 \\
\hline & 125,000 & 3.27 & 3.08 & 33.14 & 34.84 & 16.85 & 16.59 \\
\hline & 83,333 & 3.08 & 2.86 & 33.21 & 35.38 & 17.25 & 16.76 \\
\hline \multicolumn{2}{|c|}{$\operatorname{RLSD}(0.05)$} & NS & NS & NS & NS & NS & NS \\
\hline
\end{tabular}

NS: not significant according to RLSD at $\mathrm{P} \leq 0.05$

\section{DISCUSSION}

The results of the current study revealed that based on increased nitrogen fertilizer (up to $138 \mathrm{~kg} / \mathrm{ha}$ ) there was a significant increase in seed yield /ha but there was no significant difference from $184 \mathrm{~kg} \mathrm{~N} / \mathrm{ha}$. These results might be due to the positive effect rendered by nitrogen fertilizer on total chlorophyll content of the plant leaves and leaf area/plant which reflected in the increased photosynthesis rate of plants and finally the increased growth rate of plants [2] and [3]. In addition, increased nitrogen fertilizer rate significantly increased the seed yield components such as number of branches/plants, number of heads/plants, seed weight/plant and 100-seeds weight which reflected in increased seed yield/ha [1] [4] [6]. With regards to the positive effects rendered by increased nitrogen fertilizer rate on seed protein and oil contents, the study also showed that the protein content has increased in seeds whereas the oil content got decreased. This might be due to the role played by nitrogen as a main component in the production of amino acids, the basic element of proteins [1], [6]. The negative relationship between protein and oil contents was confirmed with earlier studies ([21] [22] [9]. With regards to the effects of plant density on safflower yield and quality, the results showed that as the plant density decreased, the seed weight/plant and seed yield/ha got significantly increased. This might be due to the compensation effect through increased seed yield components especially due to the increased number of branches/plants, number of heads/plant and seed weight/plant in the low plant density as a result of the wide plant spacing, high leaf area and high photosynthesis rate [11] [13]. With increased photosynthesis rate, there was an automatic increase in protein and oil processing [14] and [21].

\section{CONCLUSION}

The results obtained from the study concluded that increased nitrogen fertilizer rate significantly increased the safflower seed yield and yield components up to $138 \mathrm{~kg} \mathrm{~N} / \mathrm{ha}$. The plant density of 83,333 plants / ha was the highest in seed yield/ha, yield components, protein and oil contents of seeds when compared with 250,000 plants/ha and 125,000 plants/ha. Increased nitrogen fertilizer rate significantly increased the protein content and decreased the oil content of safflower seeds.

\section{ACKNOWLEDGEMENT}

The authors of this study offer their thanks and respective to King Abdulaziz City for Science and Technology (KACST) at Riyadh, Saudi Arabia for fund the Ph.D. research project under the grant no. (0001-009- $04-17$ 1). Therefore, acknowledge with thanks (KACST) technical and financial support. 
Albogami, M.G et al., 2018. Effect of Nitrogen Fertilizer Rates and Plant Densities on Safflower (Carthamus tinctorius L.) yield and Quality under Arid Land Conditions/ American-Eurasian Journal of Sustainable Agriculture. 12(4) October-December 2018, Pages: 1-6. DOI: 10.22587/aejsa.2018.12.4.1

\section{REFERENCES}

[1] Kulekci, M., Polat, T. and Ozturk, E. (2009). The determination of economically optimum nitrogen dose in safflower production under dry conditions. Bulg. J. Agric. Sci., 15: 341-346.

[2] Armah-Agyeman, G., J. Loiland, R. Karow and A. N. Hang, 2002. Safflower. Dryland Cropping Systems, EM 8792.

[3] Siddiqui, M. H. and F. C. Oad, 2006. Nitrogen requirement of safflower (Carthamus tinctorius L.) for growth and yield traits. Asian J. Plant Sci., 3: 563-565.

[4] Naseri, R. and Mirzaei, A. (2010). Response of yield and yield components of Safflower (Carthamus tinctorius L.) to seed inoculation with Azotobacter and Azospirillum and different nitrogen levels under dry land condition. American-Eurasian Journal of Agricultural and Environmental Sciences, 9(4): 445449.

[5] Strasil, Z. and Vorlicek, Z. (2002). The effect of nitrogen, sowing rates and site on yield and yield and yield components of selected varieties of safflower. Rostlinna Vyroba 48 (70: 307-311.

[6] El-Nakhlawy, F.S. (1991). Response of Safflower (Carthamus tinctorius L.) to different levels of nitrogen, phosphorus and potassium. Acta Agron. Hung. 40: 87-92.

[7] Christos, A.D. and Sioulas, C. (2008). Safflower yield, chlorophyll content, photosynthesis and water use efficiency response to nitrogen fertilization under rain-fed conditions. Indust. Crops Prod., 27: 75-85.

[8] Golzarfar, M., Shirani, R., Delkhosh, B. and Bitarafan, Z. (2012). Safflower response to different nitrogen and phosphorus fertilizer rates in two planting seasons. Zemadirbysit , Agriculture, 20 : 159-166.

[9] Eryigit, T., Yıldırım,Y., Kumlay, A.M. and Sancaktaroglu,S. (2015). The effects of different row distances and nitrogen fertilizer rates on yield and yield components of safflower. 3rd International Conference on Biological, Chemical \& Environmental Sciences (BCES-2015) 21-22.

[10] Bitarafan, Z., A.H. Shirani-Rad, and B. Delkhosh, Nitrogen Rates and Sowing Date Effect on Yield and Oil Content of Spring Safflower. International Journal of Science and Advanced Technology 2011. 1(6); 12-19.

[11] Elfadi E, Reinbrecht C, Frick C, Claubein W. (2009). Optimizing of nitrogen rate and seed density for safflower (Carthamus tinctorius, L.) production under low farming conditions in temperate climate. Field Crops Res., 14: 2-104.

[12] Hamza, M. (2015). Influence of different plant densities on crop yield of six safflower genotypes under Egyptian newly reclaimed soils conditions. International Journal of Agriculture and Crop Sciences. 8 (6): 8-173.

[13] Oad, M.A. and Samo,S.M. (2002). Inter and intra row spacing effect on the growth seed yield and oil content of safflower. Asian J.Plant.Sci.,1:18-19.

[14] Barzegar, A.B. and Rezai, A. (1998). Yield, yield components and the distribution patterns of safflower. 5th Congress of agronomy and plant breeding 9 - 13 September, Tehran University.

[15] Vaghar, M.S. Shamsi, K. Kobraee, S. and Behrooz, R. (2014). The effect of planting row interval and plant density on the phonological traits of safflower (Carthamus tinctorius L) under dry condition. International J. Biosciences 4(12):202-208

[16] Pansu M. and Gautherou J. (2006). Handbook of Soil Analysis. Mineralogical, Organic and Inorganic Methods. Springer.com.

[17] EL-Nakhlawy, F. S. and Ghandorah, M. (2008). Practical Practices of Field Crop Production. Sci. Pub.Center, King Abdulaziz University, Jeddah, Saudi Arabia.

[18] AOAC (2000). Association of Official Analytical Chemists. Official Methods of Analysis (17th Ed.). Washington DC.

[19] EL-Nakhlawy, F.S. (2010). Experimental Design and Analysis in Scientific Research.Sci. Pub.Center, King Abdulaziz University, Jeddah, Saudi Arabia.

[20] SAS (2014). SAS Institute Inc., Cary Nc., USA (Soft Ware Statistical Program.

[21] El-Nakhlawy, F.S. (2004). Oil and Fatty Acids of Five Oil Seed Crops grown under different planting Dates and Photoperiod Treatments. Acta Agronon. Hung. 53: 54 - 68.

[22] El-Nakhlawy, F.S. and Shiboob, M.H. (2011). Evaluation of Nine Oil Crops for Fatty Acid Constituents of their Oils. JKAU: Met., Env. \& Arid land Agric.Sci.22 No.1:51-59.

[23] Jayaraman J. (1988). Laboratory Manual in Biochemistry. Third Edition, Wiley Eastern

Ltd., New York, USA. 